\title{
Rhodotorula cresolica sp. nov., a Cresol-Assimilating Yeast Species Isolated from Soil
}

\author{
WOUTER J. MIDDELHOVEN ${ }^{1 *}$ AND FRANS SPAAIJ ${ }^{2}$ \\ Laboratorium voor Microbiologie, Wageningen Agricultural University, 6700 EJ Wageningen, \\ The Netherlands, ${ }^{1}$ and Labor für Schimmelpilze und Hefen, 72076 Tübingen, Germany ${ }^{2}$
}

\begin{abstract}
A cresol-assimilating yeast strain of a previously undescribed species belonging to the genus Rhodotorula was isolated from soil. The new strain differs from the previously described species of the genus in its pattern of assimilation of carbon and nitrogen compounds, $G+C$ content, and low levels of DNA-DNA-homology. The new species Rhodotorula cresolica is described. The type strain is CBS 7998.
\end{abstract}

Several yeast species are able to assimilate a great variety of benzene compounds as sole sources of carbon and energy. Strains displaying this property have been found in culture collections $(5)$ and in several natural habitats $(7,12)$. In a previous publication, the isolation of yeast strain $\mathrm{G} 36^{\mathrm{T}}(\mathrm{T}=$ type strain) from soil polluted with ortho-cresol was reported (7). Inoculation with strain $\mathrm{G}^{3} 6^{\mathrm{T}}$ of soil contaminated with $o$-cresol accelerated the degradation of this pollutant (7), thus demonstrating that strain $\mathrm{G} 36^{\mathrm{T}}$ can successfully compete for ortho-cresol with the general soil flora. Identification of this organism was based on physiological properties (i.e., the pattern of assimilation of carbon and nitrogen compounds). The results revealed similarity between strain G36 ${ }^{\mathrm{T}}$ and Rhodotorula aurantiaca (Saito) Lodder. However, strain G36 ${ }^{\mathrm{T}}$ lacked the red pigment and the tendency to elongate to cylindrical cells characteristic of $R$. aurantiaca. Moreover, it grew without vitamins. This prompted us to reconsider the taxonomic position of strain $G 36^{\mathrm{T}}$. The results of DNA base composition and DNA-DNA reassociation studies led us to propose a novel species, named Rhodotorula cresolica Middelhoven et Spaaij. Strain G36 (= CBS 7998) is the type strain of this new taxon.

\section{MATERIALS AND METHODS}

Isolation of the strain. Acidic sandy soil $\left(\mathrm{pH}\left[\mathrm{H}_{2} \mathrm{O}\right] 3.9\right.$; moisture content $10 \%$ ) obtained just beneath the litter layer of a 130 -year-old oak grove at Wageningen, The Netherlands, was supplied with ortho-cresol (about $20 \mathrm{mg} / 500$ $\mathrm{g}$ of soil). The contaminated soil was incubated at $10^{\circ} \mathrm{C}$ in a covered beaker for 2 months. From time to time the contents were mixed with a sterile spatula. Yeasts were enriched by shaking a slurry containing $2.5 \mathrm{~g}$ of polluted soil with 10 $\mathrm{ml}$ of $1 \%$ glucose- $1 \%$ yeast extract for 2 days at $20^{\circ} \mathrm{C}$. This culture was used as an inoculum for slant cultures (6) containing 0 -cresol as the sole carbon source. Strain $\mathrm{G} 36^{\mathrm{T}}$ was obtained by streaking material from the zone of growth on YM agar. The strain was maintained in the same medium.

Characterization of the strain. Strain $\mathrm{G} 6^{\mathrm{T}}$ was examined for its morphological, cultural, and physiological properties by using the standard methods adopted for yeast identification (15). Utilization of carbon and nitrogen sources was examined at $25^{\circ} \mathrm{C}$ on a rotary shaker rotating at a speed of $100 \mathrm{rpm}$. Utilization of nitrogen sources was confirmed by the auxanographic technique. Assimilation of potentially toxic benzene compounds was studied by the slant culture method (6).

To determine the DNA base composition, cells were grown in $2 \%$ GYP (15) at $25^{\circ} \mathrm{C}$ on a rotary shaker until the late $\log$ phase. Cells were harvested by centrifugation, washed in water and saline EDTA $(0.1 \mathrm{M} \mathrm{NaCl}, 0.15 \mathrm{M}$ EDTA) and broken with a French press. DNA was isolated by the method of Cryer et al. (2) and was purified by centrifugation in a cesium chloride-ethidium bromide gradient as described by Maniatis et al. (4). The purity of the DNA preparation was checked by the spectrophotometric method (4). The base composition of the DNA was determined in $0.1 \times \mathrm{SSC}(1 \times \mathrm{SSC}$ is $0.15 \mathrm{M}$ sodium chloride plus 0.015 $\mathrm{M}$ sodium citrate, $\mathrm{pH} 7.0$ ) from the thermal denaturation profile (9) with a

* Corresponding author. Mailing address: Laboratorium voor Microbiologie, Wageningen Agricultural University, P.O. Box 8033, 6700 EJ Wageningen, The Netherlands.
Gilford Response UV-VIS spectrophotometer and thermal programming software heating at a rate of $0.1^{\circ} \mathrm{C} / \mathrm{min}$. The $\mathrm{G}+\mathrm{C}$ content was calculated by the following formula: $\mathrm{G}+\mathrm{C}$ content $=\left(2.08 \times T_{m}\right)-106.4$, where $T_{m}$ is the thermal denaturation temperature. A standard preparation of Candida parapsilosis CBS 604 DNA $\left(T_{m}, 70.6^{\circ} \mathrm{C}\right)$ was included as a control in every determination. The value reported below is the mean \pm standard deviation from three determinations. The extent of DNA-DNA reassociation was determined by using the same instrument $(3,13)$.

Ubiquinone isoprenologs were extracted and purified as described previously $(16,17)$. To determine the type of coenzyme $\mathrm{Q}(\mathrm{CoQ})$, we used reverse-phase thin-layer chromatography, Merck HPTLC RP-18 F254s plates, and acetoneacetonitrile $(80: 20, \mathrm{vol} / \mathrm{vol})$ as the developing solvent (8). The separated components were detected under UV light at $254 \mathrm{~nm}$.

\section{RESULTS}

Latin diagnosis of Rhodotorula cresolica Middelhoven et Spaaij sp. nov. In medio liquido dextrosum et peptonum et extractum levidinis continenti post 3 dies ad $20^{\circ} \mathrm{C}$ cellulae sunt globosae aut ovoideae $(2-11 \times 2-9 \mu \mathrm{m})$, singulae aut binae. Post hebdomades 4 sedimentum adest. Pelliculum non formantur. Cultura in agar dextrosum et peptonum et extractum levidinis post hebdominades $4,20^{\circ} \mathrm{C}$, viscosa, crema, glabra, nitida, margo integer. In agara farina Zea maydis confecto post dies $7,20^{\circ} \mathrm{C}$ nec mycelium nec pseudomycelium formantur. Fermentatio nulla. Assimilat D-glucosum, D-glucosaminum (lente), D-ribosum (lente), D-xylosum, D-arabinosum (lente), sucrosum, maltosum, trehalosum, $\alpha$-methyl-D-glucosidum, cellobiosum (lente), arbutinum, melezitosum, glycerolum, ribitolum, xylitolum, glucitolum, mannitolum, glucono- $\delta$-lactonum, acidum 2-ceto-D-gluconicum, acidum 5-ceto-D-gluconicum, acidum gluconicum, acidum glucuronicum, acidum galacturonicum, acidum lacticum (lente), acidum succinicum, acidum citricum (lente), ethanolum, propano-1,2-diolum, acidum quinicum, acidum saccharicum (lente). Non assimilat D-galactosum, L-sorbosum, L-arabinosum, L-rhamnosum, salicinum, melibiosum, lactosum, raffinosum, inulinum, amylum solubile, erythritolum, L-arabinitolum, galactitolum, inositolum, methanolum, butano-2,3-diolum. Assimilat kalii nitratum, sodii nitrosum, ethylaminum, L-lysinum, cadaverinum, creatinum, creatininum. Non assimilat glucosaminum et imidazolum.

Vitamina externa ad crescentiam non necessariae sunt. Crescit in $25^{\circ} \mathrm{C}$, non crescit in $30^{\circ} \mathrm{C}$. Materiae amyloideae non formantur. Ureum finditur. Proportio guanini plus cytosini in acido deoxyribonucleico $49.2 \pm 0.4$ per centum.

Typus: CBS 7998 isolatus ex terra Wageningen in collectione zymotica Centraalbureau voor Schimmelcultures, Delphi Batavorum.

Morphological characteristics of the species. After 5 days of growth in broth containing glucose $(2 \%$, wt/vol), yeast extract $(0.5 \%, \mathrm{wt} / \mathrm{vol})$, and peptone $(1 \%, \mathrm{wt} / \mathrm{vol})$ at $20^{\circ} \mathrm{C}$, the cells are globose to ovoid ( 2 to 11 by 2 to $9 \mu \mathrm{m}$ ). A pellicle is not 
TABLE 1. Assimilation of carbon compounds

\begin{tabular}{|c|c|}
\hline Compound & $\begin{array}{l}\text { Assimilation by } \\
\text { strain } \mathrm{G} 36^{\mathrm{T}}\end{array}$ \\
\hline \multicolumn{2}{|c|}{ D-Glucose } \\
\hline \multicolumn{2}{|c|}{ 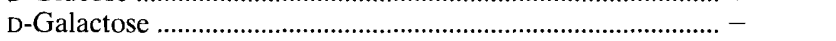 } \\
\hline \multicolumn{2}{|c|}{ L-Sorbose } \\
\hline \multicolumn{2}{|c|}{ D-Glucosamine } \\
\hline \multicolumn{2}{|c|}{ D-Ribose } \\
\hline \multicolumn{2}{|c|}{ D-Xylose } \\
\hline \multicolumn{2}{|c|}{ 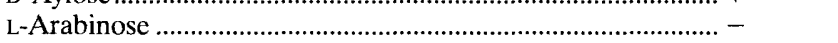 } \\
\hline \multicolumn{2}{|c|}{ D-Arabinose } \\
\hline \multicolumn{2}{|c|}{ L-Rhamnose } \\
\hline \multicolumn{2}{|c|}{ Sucrose } \\
\hline \multicolumn{2}{|c|}{ Maltose } \\
\hline \multicolumn{2}{|c|}{$\alpha \alpha$-Trehalose } \\
\hline \multicolumn{2}{|c|}{ Methyl- $\alpha$-D-glucoside } \\
\hline \multicolumn{2}{|c|}{ Cellobiose } \\
\hline \multicolumn{2}{|c|}{ Salicin } \\
\hline \multicolumn{2}{|c|}{ Arbutin } \\
\hline \multicolumn{2}{|c|}{ 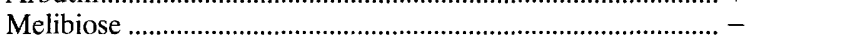 } \\
\hline \multicolumn{2}{|c|}{ Lactose } \\
\hline \multicolumn{2}{|c|}{ Raffinose } \\
\hline \multicolumn{2}{|c|}{ Melezitose } \\
\hline \multicolumn{2}{|c|}{ Inulin } \\
\hline \multicolumn{2}{|c|}{ Starch } \\
\hline \multicolumn{2}{|l|}{ Glycerol........ } \\
\hline \multicolumn{2}{|c|}{ 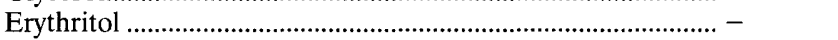 } \\
\hline Ribitol .................. & ......... \\
\hline Xylitol............................ & ....... \\
\hline L-Arabinitol .... & ....... - \\
\hline D-Glucitol ............. & …...... \\
\hline D-Mannitol......... & $\ldots \ldots+$ \\
\hline Galactitol ........... & ........ \\
\hline myo-Inositol.... & ......... - \\
\hline D-Glucono-1,5-1 & $\ldots . . .+$ \\
\hline 2-Keto-D-glucol & (n...... \\
\hline 5-Keto-D-glucona & ......... \\
\hline D-Gluconate.... & ......... \\
\hline D-Glucuronate & $\ldots \ldots .$. \\
\hline D-Galacturona & + \\
\hline DL-Lactate........ & ........ D \\
\hline Succinate ................. & ........ + \\
\hline 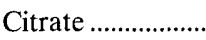 & $\ldots \ldots . . . D$ \\
\hline Methanol. & $\ldots \ldots .$. \\
\hline Ethanol ............. & + \\
\hline Propane-1,2-diol. & .......... \\
\hline Butane-2,3-diol... & ......... - \\
\hline Quinate.. & $\ldots \ldots \ldots+$ \\
\hline Saccharate... & $\ldots . . . . \mathrm{D}$ \\
\hline Galactonate ......... & $\ldots . . . . \mathrm{D}, \mathrm{W}$ \\
\hline n-Hexadecane... & $\ldots \ldots .$. \\
\hline
\end{tabular}

$a+$, positive; - , negative; $\mathrm{D}$, delayed; $\mathrm{W}$, weak.

formed, but a sediment is present. A streak culture in this medium solidified with agar $(2 \%)$ after 4 weeks at $20^{\circ} \mathrm{C}$ is cream colored, mucoid, glistening, and smooth with entire margins. No mycelium or pseudomycelium is formed in a slide culture in corn meal agar after 5 days at $20^{\circ} \mathrm{C}$.

Alcohol fermentation. No detectable gas is formed during alcohol fermentation.

Assimilation of carbon and nitrogen compounds. The assimilation of carbon compounds and the assimilation of nitrogen compounds are shown in Tables 1 and 2 , respectively. The assimilation of benzene compounds is shown in Table 3 .

Other characteristics. External vitamins are not required. Grows at $25^{\circ} \mathrm{C}$, but not at $30^{\circ} \mathrm{C}$. No growth occurs in $50 \%$ glucose-yeast extract agar and in the presence of 0.01 or $0.1 \%$ cycloheximide. Amyloid compounds are not produced. Urea is hydrolyzed. The color reaction with Diazonium Blue B is positive. The $\mathrm{G}+\mathrm{C}$ content of the nuclear DNA is $49.2 \pm 0.4$ mol\%. The major CoQ is CoQ 10.

Etymology. The specific epithet cresolica pertains to cresols; cresolica, referring to the ability to assimilate cresols.

Origin and deposits. Strain $\mathrm{G} 36^{\mathrm{T}}$ was isolated from soil in Wageningen, The Netherlands. Type strain CBS 7998 has been deposited in the yeast culture collection of the Centraalbureau voor Schimmel-cultures in Delft, The Netherlands, and in the culture collection of the Laboratory of Microbiology in Wageningen, The Netherlands.

\section{DISCUSSION}

Besides the differences in utilization of carbon and nitrogen compounds (Table 4), our isolate lacks the red pigment, the tendency to elongate to cylindrical cells, and the thiamine requirement characteristic of strains belonging to $R$. aurantiaca. The type strain of $R$. aurantiaca, ATCC 32770 (= CBS 317 ), also does not assimilate phenol, the cresols, hydroquinone, and resorcinol, but grows slowly on 4-hydroxybenzoic acid and 2,5-dihydroxybenzoic acid (data not shown). The two taxa are genetically distinct and represent separate anamorphic species. This conclusion was based on the $\mathrm{G}+\mathrm{C}$ values, which differed by more than $2 \mathrm{~mol} \%$, and on the low level of DNADNA reassociation. The levels of reassociation between $R$. cresolica DNA and DNAs from $R$. cresolica CBS $7998^{\mathrm{T}}, R$. aurantiaca CBS 317 , and Rhodotorula pilatii CBS $7039^{\mathrm{T}}$ were 98,0 , and $20 \%$, respectively (in all cases the standard deviation was less than $5 \%$ ).

Identification of strain $\mathrm{G} 36^{\mathrm{T}}$ with the determination keys provided by Barnett et al. (1) also pointed to Rhodotorula pilatii (Jacob et al.) Weijman (Barnett et al. 1983). The type strain of this species, CBS 7039, slowly assimilated phenol, hydroquinone, and 3-hydroxybenzoic acid (data not shown). Other strains of this species have been isolated from enrichment cultures inoculated with wood or shelf fungi by using protocatecuic acid or vanillic acid as the sole energy source (12). The characteristics which differentiate the species are listed in Table 4. Again, lack of DNA-DNA reassociation excluded placement of strain $\mathrm{G}^{\mathrm{T}} 6^{\mathrm{T}}$ in this species (see above).

The pattern of assimilation of carbon and nitrogen compounds of strain $\mathrm{G} 36^{\mathrm{T}}$ is very similar to that of Leucosporidium scottii Fell et al. Nonmycelial strains of this species are sometimes isolated from soil and other habitats. $L$. scottii is known to assimilate many benzene compounds (5), including metaand para-cresol, but not ortho-cresol. Strain G36 ${ }^{\mathbf{T}}$ cannot be identified as $L$. scottii as the $\mathrm{G}+\mathrm{C}$ content of strain $\mathrm{G} 36^{\mathrm{T}}$ is $49.2 \pm 0.4 \mathrm{~mol} \%$ and the $\mathrm{G}+\mathrm{C}$ content of $L$. scottii $59.0 \mathrm{~mol} \%$

TABLE 2. Assimilation of nitrogenous compounds

\begin{tabular}{|c|c|}
\hline Compound & $\begin{array}{l}\text { Assimilation by } \\
\text { strain G36 }\end{array}$ \\
\hline \multicolumn{2}{|c|}{ Nitrate } \\
\hline \multicolumn{2}{|c|}{ Nitrite } \\
\hline \multicolumn{2}{|c|}{ Ethylamine } \\
\hline \multicolumn{2}{|c|}{ L-Lysine } \\
\hline \multicolumn{2}{|c|}{ 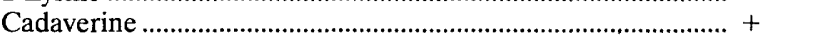 } \\
\hline \multicolumn{2}{|c|}{ Creatine } \\
\hline \multicolumn{2}{|c|}{ Creatinine } \\
\hline \multicolumn{2}{|c|}{ Glucosamine } \\
\hline \multicolumn{2}{|c|}{ 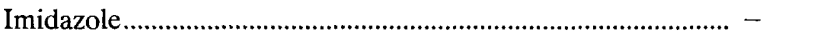 } \\
\hline
\end{tabular}


TABLE 3. Assimilation of benzene compounds as determined by the slant culture method

\begin{tabular}{|c|c|}
\hline Compound $^{a}$ & $\begin{array}{l}\text { Assimilation by } \\
\text { strain } \mathrm{G} 36^{\mathrm{T}}\end{array}$ \\
\hline \multicolumn{2}{|c|}{ Phenol (hydroxybenzene) } \\
\hline \multicolumn{2}{|c|}{ 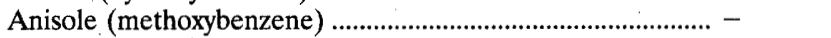 } \\
\hline \multicolumn{2}{|c|}{ Catechol $(1,2$-dihydroxy) } \\
\hline \multicolumn{2}{|c|}{ Resorcinol $(1,3$-dihydroxy) } \\
\hline \multicolumn{2}{|c|}{ 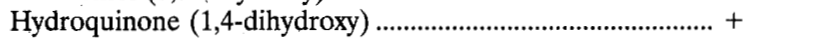 } \\
\hline \multicolumn{2}{|c|}{ 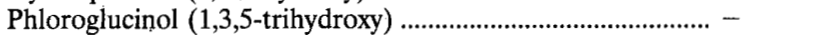 } \\
\hline \multicolumn{2}{|c|}{ 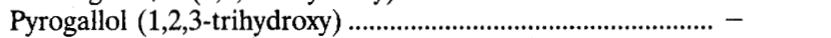 } \\
\hline \multicolumn{2}{|c|}{ ortho-Cresol (2-methylphenol) } \\
\hline \multicolumn{2}{|c|}{ meta-Cresol (3-methylphenol) } \\
\hline \multicolumn{2}{|c|}{ 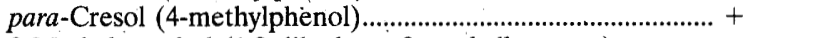 } \\
\hline \multicolumn{2}{|c|}{ 3-Methylcatechol (1,2-dihydroxy-3-methylbenzene) ............... - } \\
\hline \multicolumn{2}{|c|}{ 4-Methylcatechol (1,2-dihydroxy-4-methylbenzene) .............. } \\
\hline \multicolumn{2}{|c|}{ Orcinol (1-methyl-3,5-dihydroxybenzene) } \\
\hline \multicolumn{2}{|c|}{ Benzyl alcohol (hydroxymethylbenzene) ................................. } \\
\hline \multicolumn{2}{|c|}{ 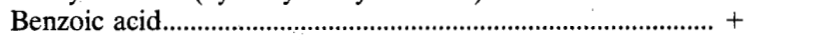 } \\
\hline \multicolumn{2}{|c|}{ 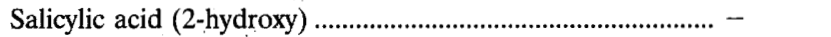 } \\
\hline 3-Hydroxybenzoic acid ................... & ......... \\
\hline 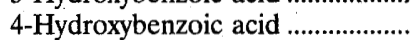 & ........... \\
\hline 2,3-Dihydroxybenzoic acid .......... & ......... \\
\hline 2,4-Dihydroxybenzoic acid ......... & ........ + \\
\hline Gentisic acid (2,5-dihydroxy)..... & .........- \\
\hline Protocatechuic acid $(3,4$-dihydro & ....... \\
\hline 3,5-Dihydroxybenzoic acid ......... & $\ldots .+$ \\
\hline $2,3,4$-Trihydroxybenzoioc acid.... & .......... - \\
\hline Gallic acid (3,4,5-trihydroxy) .... & $\ldots \ldots+$ \\
\hline Vanillic acid (3-methoxy-4-hydro & ..... + \\
\hline Isovanillic acid (3-hydroxy-4-met & $\ldots .+$ \\
\hline Veratric acid (3,4-dimethoxy)..... & $\ldots \ldots .+$ \\
\hline Syringic acid (4-hydroxy-3,5-dime & ......... - \\
\hline 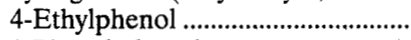 & ........ - \\
\hline 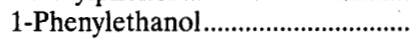 & ......... - \\
\hline 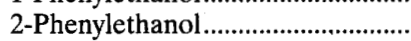 & .......... \\
\hline 2-Phenylethylamine (phenethylar & ......... \\
\hline Tyramine (4-hydroxyphenylethyla & ........ \\
\hline Phenethylene glycol (2-phenyleth & $\ldots \ldots+$ \\
\hline Acetophenone (acetylbenzene).. & .......... - \\
\hline 4-Hydroxyacetophenone.............. & ............ \\
\hline 4-Methoxyacetophenone .... & $\ldots-$ \\
\hline 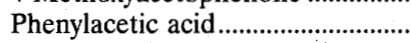 & $\ddot{. .}+$ \\
\hline 2-Hydroxyphenylacetic acid ...... & ….... \\
\hline 3-Hydroxyphenylacetic acid ... & $\ldots . \ldots W$ \\
\hline 4-Hydroxyphenylacetic acid ............... & ........ \\
\hline Homoprotocatechuic acid (3,4-dil & $\ldots . . W$ \\
\hline Homogentisic acid (2,5-dihydroxy & ...... \\
\hline DL-Mandelic acid (2-phenyl-2-hyd & $\ldots .$. \\
\hline DL-4-Hydroxymandelic acid ..... & $\ldots . .+$ \\
\hline 3-Phenylpropionic acid.... & $\ldots .+$ \\
\hline 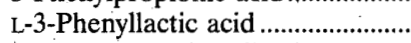 & \\
\hline DL-4-Hydroxyphenyllactic acid . & ......... \\
\hline Phenylpyruvic acid ........ & ….......- \\
\hline L-Phenylalanine ............ & ......... + \\
\hline 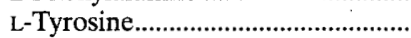 & $\ldots-$ \\
\hline trans-Anethole (4-propenylanisc & $\ldots-$ \\
\hline Cinnamic acid (trans-3-phenylpro & $\cdots+$ \\
\hline 3-Hydroxycinnamic acid ............... & .......... - \\
\hline 4-Hydroxycinnamic acid (4-cour & ........... \\
\hline 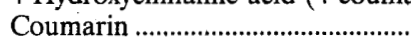 & $\ldots \mathrm{D}, \mathrm{W}$ \\
\hline Caffeic acid (3,4-dihydroxycinnar & $\ldots .+$ \\
\hline Ferulic acid (3-methoxy-4-hydrox & ......... \\
\hline Sinapinic acid (4-hydroxy-3,5-dihy & ..........- \\
\hline 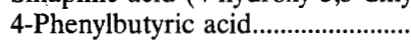 & ......... D \\
\hline 5-Phenylvaleric acid.. & \\
\hline 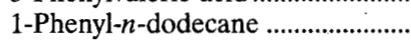 & (n....... - \\
\hline
\end{tabular}

${ }^{a}$ Benzene compounds are listed in order of side chain length.

${ }^{b}+$, positive; -, negative; $\mathrm{D}$, delayed; $\mathrm{W}$, weak.
TABLE 4. Characteristics that differentiate $R$ cresolica, $R$. aurantiaca, and R. pilatii

\begin{tabular}{lccc}
\hline \multirow{2}{*}{ Compound } & \multicolumn{3}{c}{ Utilization by: } \\
\cline { 2 - 4 } & $R$. cresolica & $R$. aurantiaca & $R$. pilatii \\
\hline L-Sorbose & $-^{a}$ &,$- \mathrm{D}$ &,$+ \mathrm{D}$ \\
D-Glucosamine &,$+ \mathrm{D}$ & - & - \\
D-Ribose &,$+ \mathrm{D}$ &,$- \mathrm{D}$ & - \\
$\alpha$-Methyl-D-glucoside & + & - & - \\
Lactose & - & - & $\mathrm{D}$ \\
DL-Lactate &,$+ \mathrm{D}$ & - &,$+ \mathrm{D}$ \\
L-Lysine & + &,+- & - \\
Cadaverine & + & - & - \\
Creatine & + & - & - \\
Creatinine & + & - & - \\
\hline
\end{tabular}

${ }^{a}-$, negative; + , positive; $\mathrm{D}$, delayed.

(14). Moreover, the major CoQs of $L$. scottii are CoQs 9 and 10 (14).

The lack of DNA similarity with any of the above-mentioned physiologically related species made defining a new taxon to accommodate our isolate unavoidable. The novel species is placed in the imperfect basidiomycetous genus Rhodotorula Harrison as strain $\mathrm{G}^{3} 6^{\mathrm{T}}$ fails to produce amyloid compounds and to grow at the expense of myo-inositol. In addition to cresols, the strain is able to assimilate numerous benzene compounds (Table 3 ). In this respect this organism resembles other basidiomycetous yeasts, such as Rhodotorula bogoriensis (Deinema) Von Arx et Weijman CBS 4101, Rhodotorula glutinis (Fresenius) Harrison St. 41, L. scottii G43, and various Trichosporon species (5). However, the ability to assimilate ortho-cresol is unique among the basidiomycetous yeasts tested (5). In a yeast collection comprised of 29 different species that were screened for assimilation of 84 different benzene compounds, only the black ascomycetous yeastlike fungus $E x$ ophiala jeanselmei (Langer.) McGinnis et Padhye was able to assimilate ortho-cresol (5). No data on the biodegradative pathway for ortho-cresol in yeasts are available. The degradative pathway for para-cresol in Trichosporon cutaneum has been elucidated $(10,11)$. Like all other yeasts tested previously, $R$. cresolica $\mathrm{G} 36^{\mathrm{T}}$ failed to grow on benzene compounds with more than one carbon side chain (e.g., xylenols and toluic and phthalic acids) or a branched carbon side chain (5).

\section{REFERENCES}

1. Barnett, J. A., R. W. Payne, and D. Yarrow. 1990. Yeasts. Characteristics an identification, 2nd ed. Cambridge University Press, Cambridge, England,

2. Cryer, D. R., R. Eccleshall, and J. Marmur. 1975. Isolation of yeast DNA, p 39-44. In D. M. Prescott (ed.), Methods of cell biology, vol. XII. Academic Press, New York, N.Y.

3. Kurtzman, C. P., J. M. Smiley, C. J. Johnson, L. J. Wickerham, and G. B. Fuson. 1980. Two closely related and heterothallic species, Pichia amylophilo and Pichia mississippiensis: characterization by hybridization and deoxyribunucleic acid reassociation. Int. J. Syst. Bacteriol. 30:208-216.

4. Maniatis, T., E. F. Fritsch, and J. Sambrook. 1982. Molecular cloning: a laboratory manual. Cold Spring Harbor Laboratory, Cold Spring Harbor, N.Y.

5. Middelhoven, W. J. 1993. Catabolism of benzene compounds by ascomycetous and basidiomycetous yeasts and yeastlike fungi. A literature review and an experimental approach. Antonie van Leeuwenhoek 63:125-144.

6. Middelhoven, W. J., I. M. de Jong, and M. de Winter. 1991. Arxula adeninivorans, a yeast assimilating many nitrogenous and aromatic compounds. Antonie van Leeuwenhoek 59:129-137.

7. Middelhoven, W. J., M. Koorevaar, and G. Schuur. 1992. Degradation of benzene compounds by yeasts in acidic soils. Plant Soil 145:37-43.

8. Nakase, T., and M. Suzuki. 1985. Taxonomic studies on Debaryomyces han senii (Zopf) Lodder et Kreger-van Rij and related species. I. Chemotaxonomic investigations. J. Gen. Appl. Microbiol. 31:49-69.

9. Owen, R. J., L. R. Hill, and S. P. Lapage. 1969. Determination of DNA base 
compositions from melting profiles in dilute buffers. Biopolymers 7:503-516. 10. Powlowski, J. B., J. Ingebrand, and S. Dagley. 1985. Enzymology of the $\beta$-adipate pathway in Trichosporon cutaneum. J. Bacteriol. 163:1136-1141.

11. Powlowski, J. B., and S. Dagley. 1985. $\beta$-Ketoadipate pathway in Trichosporon cutaneum modified for methyl-substituted metabolites. J. Bacteriol. 163:1126-1135.

12. Sampaio, J. P. 1995. Utilization of low molecular weight lignin-related aromatic compounds for the selective isolation of yeasts: Rhodotorula vanillica a new basidiomycetous yeast species. Syst. Appl. Microbiol. 17:613-619.

13. Seidler, R. J., and M. Mandel. 1971. Quantitative aspects of deoxyribonucleic acid renaturation: base composition, site of chromosome replication, and polynucleotide homologies. J. Bacteriol. 106:608-614.

14. Sugijama, J., M. Fukagawa, S.-W. Chiu, and K. Komagata. 1985. Cellular carbohydrate composition, DNA base composition, ubiquinone systems and diazonium blue b color test in the genera Rhodosporidium, Leucosporidium,
Rhodotorula and related basidiomycetous yeasts. J. Gen. Appl. Microbiol. 31:519-550.

15. van der Walt, J. P., and D. Yarrow. 1984. Methods for isolation, maintenance, classification of yeasts, p. 45-104. In N. J. W. Kreger-van Rij (ed.), The yeasts: a taxonomic study, 3rd ed. Elsevier Science Publishers, Amsterdam, The Netherlands.

16. Yamada, Y., and K. Kondo. 1972. Taxonomic significance of coenzyme Q system in yeasts and yeast-like fungi (1), p. 363-372. In A. Kocková-Kratochvilová and $\mathrm{E}$. Minárik (ed.), In Yeast models in science and technics. Proceedings of the First Specialized Symposium on Yeasts, Smolenice, 1971 Publishing House of the Slovak Academy of Sciences, Bratislava, Slovak Republic.

17. Yamada, Y., and K. Kondô. 1973. Coenzyme Q system in the classification of the yeast genera Rhodotorula and Cryptococcus, and the yeast-like genera Sporobolomyces and Rhodosporidium. J. Gen. Appl. Microbol. 19:59-77. 